\title{
Application of the Later Method Theory in the Field of Information Technology Based on Computer Statistics
}

\author{
Xingyuan Wang \\ Zhejiang Industry and Trade Vocational College, Wenzhou, China \\ w_ang_xingyuan@126.com
} Keywords: post-method pedagogy theory; mathematical statistics; teaching method; microcosmic
strategy; data analysis; matrix vector

\begin{abstract}
English teaching has a pivotal role in English teachers' teaching of higher vocational colleges. This study aimed to explore the present situation of higher vocational English teaching, and it was based on the theory of "post-method pedagogy" to explore the idea of teachers and students. This paper was respectively from the teaching interaction, teaching skills, teaching objectives and teaching content to have a survey, and the content of survey was that which aspect of the higher vocational English teaching conformed to the teaching method model and microscopic strategy under the framework of "post-method pedagogy". It was through the questionnaire, semistructured interviews and classroom observation and other methods of mathematical statistics theory to have investigation and data statistics and analysis. Results shows that some students have deviation of microscopic strategy of teaching interaction and post-method pedagogy theory, and most of the students think that language sense plays an important role in learning English. But the inspiration of teachers' teaching method can strengthen the consciousness and strategy of their own English learning. At the same time, the data shows that the English language teaching is closely linked to the social and cultural factors, the government's language policy, and this has a certain guiding significance to improve the higher vocational English teaching method.
\end{abstract}

\section{Introduction}

Since the 19th century, a large number of teaching methods have appeared in foreign language teaching, such as the grammar translation method, direct method, vocabulary method, natural method, gesture language teaching and so on[1,2]. Now many teachers realize that there does not have the best method to be suitably used for the vocational college English teachers' teaching[3]. More and more language teachers and researchers find the complexity, and they also realize that it has a great difference between the different environments[4]. Therefore, English teaching only relies on a single method, and in this situation it is difficult to have success[5,6]. The teaching methods of higher vocational English professors are also lack of adaptability. According to the post-method pedagogy theory, this paper studied the application of post-method pedagogy to have higher vocational English teaching[7]. The post-method pedagogy theory is the reasonable mode and method of higher vocational English teachers' teaching, this theory can improve the English teaching's quality and effect, at the same time it can also improve the level of higher vocational English teaching[8,9].

\section{Simple introduction of "post-method pedagogy theory"}

A. Basic concept of "post-method pedagogy"

The "post-method pedagogy" refers to the foreign language teaching ideas that put forward from the researches of western foreign language teaching, and it fundamentally exceeds the traditional "teaching method". It is not a specific teaching method, but it is an opened teaching idea. Kumaravadivelu is the main representative personage, and the definition of "post-method pedagogy" that put forward by Kumaravadivelu is "the research on the choice of method rather than the alternative method".

The "post-method pedagogy" has rich meanings and covers all aspects of content, and its main 
characteristics are:

(1) Teaching concept of "post-method pedagogy" puts the foreign language teaching as a dynamic development process that has combined action of many kinds of factors;

(2) It should not only pay attention to the improvement of students' foreign language level, but also pay attention to the cultivation of the students' ability of independent learning and cooperative learning;

(3) In the teaching concept of "post-method pedagogy", it mainly has researches on the influence of teaching theory, strategy, social and political culture system on the foreign language teaching, and it should not only pursue the reform of teaching method.

B. Basic principle and macro strategy

Professor Kumaravadivelu puts forward "post-method pedagogy" theory's three basic principles of foreign language teaching, and they are the practicability, particularity and possibility.

(1) Principle of practicability

The "post-method pedagogy" theory encourages teachers to observe, study, practice and have reflection, and they can form the practical and dynamically developmental teaching ideas about "what is the successful teaching?". At the same time, it should be pointed out that the only usage of experts' theories is not enough, and the teachers must pay attention to the knowledge and skills that conform to the specific conditions, in this way they can solve the new problems and new situations.

(2) Principle of particularity

In the special social and cultural environment and system, specific teachers can aim at the specific teaching object to implement the teaching, and the teaching conforms to the specific teaching goal, at the same time it is suitable for the specific teaching environment. The "post-method pedagogy" theory does not negate the teaching method, but its idea is "the teaching has method, and the method is not fixed". The specific teaching research and teaching practice could not prove that a kind of teaching method more superior than the other kind of teaching method. That is to say, any kind of teaching method is not the "tiger balm", and "the best teaching method" does not exist in the teaching process. The existence of any kind of teaching method has special reason, and it is only applicable to the specific teaching situation.

(3) Principle of possibility

English teaching should conform to the university English teaching's policies and requirements of our country. English teachers should earnestly study the relevant documents, and they need to make their own researches of foreign language teaching keep pace with the national and social needs and requirements. The "post-method pedagogy" theory's principle of possibility opposes the separation of students' needs of English learning and the social requirements. English teaching can not be limited to the contents of books and the teaching material, at the same time it should meet the students' needs of learning English and the social requirements.

\section{Investigation and research of teaching method mode based on the "post-method pedagogy" theory}

This research aimed to explore present situation of English teaching, and it was based on the teaching method and the "post-method pedagogy" theory to have researches on the concept of teachers and students. This paper was respectively from the teaching interaction, teaching skills, teaching objectives and teaching content to have a survey, and the content of survey was that which aspect of the university English teaching practice conformed to the microscopic strategy of the "post-method pedagogy". In this situation, the author firstly put forward two research questions:

(1) Are the teaching interactions, teaching technology, teaching goal and the teaching content and other aspects of the current higher vocational English teaching activities in keeping with the teaching idea of the post-method pedagogy theory?

(2) What does the post-method pedagogy theory's teaching problem include in the current teaching activities?

Three English teachers of higher vocational colleges were chosen to carry on this study. The first teacher is a female teacher, and she has 24 years of teaching experience. The second female teacher 
has 6 years of teaching experience. The last one is a male teacher, and he has 1 year of teaching experience. The three teachers in the study can be assumed to be teacher 1 , teacher 2 and teacher 3 , their information is shown in Table 1.

TABLE I. Basic information of teachers

\begin{tabular}{|c|l|l|l|}
\hline & Teacher $\mathbf{1}$ & Teacher $\mathbf{2}$ & \multicolumn{1}{|c|}{ Teacher 3 } \\
\hline Age & 47 & 29 & 25 \\
\hline Gender & Female & Female & Male \\
\hline Teaching age & 25 & 6 & 1 \\
\hline Professional title & $\begin{array}{l}\text { Associate } \\
\text { professor }\end{array}$ & Lecturer & Teaching assistant \\
\hline Education background & Master & Bachelor & Bachelor \\
\hline
\end{tabular}

This paper was mainly aimed at the university teachers to carry on interview and questionnaire survey, at the same time it chose the form of classroom observation, investigation and discussion to carry out data collection of the teachers' students. And then it had the qualitative and quantitative comprehensive analysis on the collected data[14-16]. Quantitative analysis was mainly considered from the perspective of questionnaire analysis. This paper was based on the five-point scale to have the consideration of the teaching interaction, teaching skills, teaching objectives and teaching content, and the involved problems mainly had the way of learning English, the situation of answering the question in the classes, the teachers' ability of solving the problems, students' outstanding ability of learning English and students' motivation in English learning. Then it used SPSS statistical software to have statistics analysis, and qualitative analysis was mainly from interview, observation and discussion to carry on the collection of data information.

The formula of SPSS statistics method is[17]: $x_{i j}=\bar{X}+\left(\bar{X}_{i}-\bar{x}\right)+x_{i j}-x_{i}$

In which, $x_{i j}$ is the observed value of data, $\bar{x}$ is the average value $\hat{\mu}$.

$\overline{x_{i}}-\bar{x}$ is the estimates of treatment effect $\hat{\tau}_{i}, x_{i j}-x_{i}$ is the residual value $\hat{e}_{i j}$.

At the same time the total mean vector of research samples can be expressed as[18]:

$$
\underset{p \times 1}{\mu}\left(\begin{array}{l}
\mu_{1} \\
\mu_{2} \\
\cdots \\
\mu_{p}
\end{array}\right)
$$

At the same time the confidence interval of each data's weight $\mu i$ is $p=1-\alpha$.

Sii is the covariance matrix, and $\mathrm{S}$ is the variance value of the first $\mathrm{i}$ data variable.

\section{Data statistical analysis}

This paper aimed at the classes of the teachers that had investigation and interview, and it was respectively from the teaching interaction, teaching skills, teaching objectives and teaching content to carry on the analysis, and the content of analysis was that which aspect of these four aspects conformed to the teaching method model and microscopic strategy under the framework of "postmethod pedagogy". The total number of issued questionnaires was 110 , and the number of returned valid questionnaires was 104 . The following is the statistical analysis that based on the investigated data.

TABLE II. The method of extracurricular reading to learn English

\begin{tabular}{|c|c|c|c|c|c|}
\hline & Frequency & Percentage & $\begin{array}{c}\text { Effective } \\
\text { percentage }\end{array}$ & $\begin{array}{c}\text { Cumulative } \\
\text { percentage }\end{array}$ \\
\hline Effectiveness & No & 48 & 46.1 & 46.1 & 46.1 \\
\hline & Yes & 56 & 53.9 & 53.9 & 100.0 \\
\hline & Total & 104 & 100.0 & 100.0 & \\
\hline
\end{tabular}

From Table 2 we can see that $53.9 \%$ of the students chose the method of extracurricular reading to learn English, and it mainly included the books and newspapers. It shows that everyone is based on personal interest to have wide development of the English reading.

TABLE III. The method of taking part in the English training to learn English

\begin{tabular}{|l|c|l|l|l|l|}
\hline & & Frequency & Percentage & Effective percentage & Cumulative percentage \\
\hline Effectiveness & No & 54 & 51.9 & 51.9 & 51.9 \\
\hline & Yes & 50 & 48.1 & 48.1 & 100.0 \\
\hline & Total & 104 & 100.0 & 100.0 & \\
\hline
\end{tabular}

Table 3 shows that $48.1 \%$ of the students took part in the English training school to learn English, 
and they used this method to improve their English level.

From the method of using network and taking part in campus activities to learn English in Table 4, it can be known that $34.6 \%$ of the students used network to carry on the English learning, but only $10.6 \%$ of the students took part in campus activities to learn English. The situation of using the outside method to learn English learning is not a lot.

TABLE IV. The method of using network and taking part in campus activities to learn English

\begin{tabular}{|c|c|c|c|c|c|}
\hline & & Frequency & Percentage & Effective percentage & Cumulative percentage \\
\hline \multirow{2}{*}{\begin{tabular}{c} 
Use the network \\
\cline { 2 - 6 }
\end{tabular}} & No & 68 & 65.4 & 65.4 & 65.4 \\
\cline { 2 - 6 } $\begin{array}{c}\text { Take part in campus } \\
\text { activities }\end{array}$ & No & 93 & 34.6 & 34.6 & 100.0 \\
\cline { 2 - 6 } & Yes & 11 & 10.6 & 89.4 & 89.4 \\
\hline
\end{tabular}

From the situation of students answered questions and teachers dealt with problems in class in Table 5, it can be known that $12.5 \%$ of the students never answered the question, and $76.9 \%$ of the students were willing to answer the question, and the active students also accounted for $10.6 \% .4 .8 \%$ of the teachers did not have reaction, and $22.1 \%$ of the teachers didn't want to answer the questions, but the teachers' proportion of answering and discussing the problem was $73.1 \%$.

TABLE V. The situation of students answered questions and teachers dealt with problems in class

\begin{tabular}{|c|c|c|c|c|c|}
\hline & & Frequency & Percentage & $\begin{array}{c}\text { Effective } \\
\text { percentage }\end{array}$ & $\begin{array}{l}\text { Cumulative } \\
\text { percentage }\end{array}$ \\
\hline \multirow{3}{*}{ Students answer questions in class } & Never & 13 & 12.5 & 12.5 & 12.5 \\
\hline & Answer the questions & 80 & 76.9 & 76.9 & 89.4 \\
\hline & Actively & 11 & 10.6 & 10.6 & 100.0 \\
\hline \multirow{3}{*}{ Teachers deal with problems } & Answer and discuss the questions & 76 & 73.1 & 73.1 & 73.1 \\
\hline & Don't want to answer & 23 & 22.1 & 22.1 & 22.1 \\
\hline & No response & 5 & 4.8 & 4.8 & 100.0 \\
\hline
\end{tabular}

From the students' excellent ability of learning English in Table 6, it can be known that 14.4\% of the students were good at listening, and students' reading ability stood first, its proportion was $54.8 \%$; the second was the ability of speaking, its proportion was $18.3 \%$; and the third was the ability of listening, its proportion was $11.5 \%$. It also can be obviously seen that the preponderant ability of students was reading, and the distances between other abilities of listening, speaking and writing were not big.

TABLE VI. The situation of students' motivation of learning English

\begin{tabular}{|c|c|c|c|c|c|}
\hline & & Frequency & Percentage & $\begin{array}{c}\text { Effective } \\
\text { percentage }\end{array}$ & $\begin{array}{c}\text { Cumulative } \\
\text { percentage }\end{array}$ \\
\hline \multirow{4}{*}{$\begin{array}{c}\text { Effective } \\
\text { ness }\end{array}$} & $\begin{array}{c}\text { Get high } \\
\text { scores of test }\end{array}$ & 36 & 34.6 & 34.6 & 34.6 \\
\cline { 2 - 6 } & Have interest & 19 & 18.3 & 18.3 & 52.9 \\
\cline { 2 - 6 } & Go abroad & 34 & 32.7 & 32.7 & 85.6 \\
\cline { 2 - 6 } & Social need & 15 & 14.4 & 14.4 & 100.0 \\
\hline
\end{tabular}

From Table 7 it is known that the main reason of the students had English learning was to get high scores of tests, and its proportion was $34.6 \%$; the second was to go abroad, and its proportion was $32.7 \%$; the third was to have interest, and its proportion was $18.3 \%$; the last was the social need, and its proportion was $14.4 \%$.

TABLE VII. The situation of students' excellent ability of learning English

\begin{tabular}{|c|c|c|c|c|c|}
\hline & & Frequency & Percentage & $\begin{array}{c}\text { Effective } \\
\text { percentage }\end{array}$ & $\begin{array}{l}\begin{array}{l}\text { Cumulative } \\
\text { percentage }\end{array} \\
\end{array}$ \\
\hline \multirow{6}{*}{$\begin{array}{c}\text { Effective } \\
\text { ness }\end{array}$} & Listening & 15 & 14.4 & 14.4 & 14.4 \\
\hline & Speaking & 19 & 18.3 & 18.3 & 32.7 \\
\hline & Reading & 57 & 54.8 & 54.8 & 87.5 \\
\hline & Writing & 12 & 11.5 & 11.5 & 99.0 \\
\hline & Nothing & 1 & 1.0 & 1.0 & 100.0 \\
\hline & Total & 104 & 100.0 & 100.0 & 100.0 \\
\hline
\end{tabular}

\section{Conclusion}

English teaching is difficult to have big effect when it only relies on the traditional education mode. So this paper started from the method of post-method pedagogy to carry on the investigation and test of higher vocational English teaching. The results showed that $50 \%$ of the students were willing to have reading, participate in the English training and use of network, and appropriately 
participate in campus activities. The situations of questions and answers of teachers' teaching and students' learning in class, and the analyses on students' motivation of learning English demand that we should strengthen the teaching interaction, teaching skills, teaching goal and the teaching content and other aspects. It has to realize the teachers' teaching, at the same time it needs to fully give play to students' autonomy. In this way it can achieve the initiative action, at the same time it can also rapidly improve the English level. At the same time it should strengthen application of post-method pedagogy in the higher vocational English teaching, and it should constantly improve the quality and the effect of higher vocational English teaching, and in this way it can improve the level of higher vocational English teaching.

\section{References}

[1] Li Chen. The "post-method pedagogy" era of language teaching .Basic English education, 2009(03):13-16.

[2] Liqing Chen. Research on post-method pedagogy teaching mode of English reading .Shanghai: Shanghai foreign language university, 2011(08):28-31.

[3] Xiaoguang Cheng. Research of foreign languages teaching method in the age of post-method pedagogy .Journal of Tianjin foreign studies university, 2011(05):63-68.

[4] Jinwei Dong. Introduction of "understanding language teaching method, from method to the post-method pedagogy" .Modern language, 2008(10):99-101.

[5] Jinwei Dong. Foreign language teaching from the perspective of post-method pedagogy: features and elements. Language teaching theory and practice, 2009(01):09-12.

[6] Jinwei Dong. New perspective of EFL teaching -- principles and revelation of post-method pedagogy teaching .Journal of Guangdong university of foreign studies, 2010(04):101-104.

[7] Wei Dan. Review of "exceeding teaching method: macro strategy of language teaching" . Language boundary, 2010(02):74-76.

[8] Meiqiqige. Analysis on English learners' demand under the guidance of "post-method pedagogy era" teaching theory.Hohhot: Inner Mongolia normal university, 2010(07):62-65.

[9] LuHe.English curriculum standard of full-time compulsory education (Revised draft). English Study,2009(12):67-71.

[10] Dingfang Shu. Discussion of foreign language classroom teaching new model .Language boundary, 2011(03):21-24.

[11] Jianmin Tao. System construction of "post-method pedagogy era" beliefs about language teaching and foreign Chinese teaching method.Journal of the Chinese Institute of Jinan University, 2007(06):62-65.

[12] Qiufang Wen. Research methods of practical linguistics and thesis writing.Beijing: foreign language teaching and research press, 2010(08):37-39.

[13] Heping $\mathrm{Wu}$, Weimin Zhang. The reconstruction of the foreign language teaching method in the era of post-method pedagogy .Journal of curriculum, teaching materials, teaching methods, 2011(04):11-13.

[14] Fen Xue. The "post-method pedagogy" perspective of foreign language teaching .Journal of Tianjin normal university (basic education edition), 2010(02):59-62.

[15] Yuqi Zheng, Meihua Chen. Tentative study on the English teaching in the era of "postmethod pedagogy".Language and foreign language teaching, 2011(10):33-35.

[16] Jiming Zhou, Min Lv, Guidong Li. From "method" to "post-method pedagogy", how far are we from? .Journal of foreign language world, 2008(05):27-30.

[17] ZhengPing Zeng. Research of English teachers' teaching method view under the perspective of post-method pedagogy.Chengdu: Sichuan normal university, 2010(02):49-51.

[18] Tongbing Zhang, Junhua Ding. Review of Chinese foreign language education history . Research of basic education in foreign language teaching, 2012(11):36-39. 